\title{
ETIKA DAN TANGGUNG JAWAB JURNALIS (STUDI PEMBERITAAN HOAX MELALUI MEDIA ONLINE DI KOTA MAKASSAR)
}

\author{
Oleh : Andi Fadli \\ Dosen Jurusan Jurnalistik Fakultas Dakwah dan Komunikasi UIN \\ Alauddin Makassar \\ Email : andimuhfadli75@gmail.com
}

\begin{abstract}
Abstrak
Pengaruh besar digitalisasi teknologi informasi makin dirasakan saat ini. Pada konteks penyebaran informasi, digitalisasi membuka tranformasi atau pertukaran informasi dan pengetahuan pada arena yang lebih luas dengan jejaring yang serba cepat dan menjangkau hingga ke pelosok daerah. Digitalisasi teknologi informasi juga membawa informasi semakin dekat dengan individu baik dari segi waktu dan tempat. Lebih pesat lagi karena lahirnya aplikasi telepon pintar berteknologi digital, membuka akses terhadap informasi berlangsung kapan saja, dan di mana saja. Dengan berbekal aplikasi telepon pintar setiap individu bahkan dapat berperan secara langsung sebagai penyebar pesan atas peristiwa yang terjadi di sekelilingnya. Perkembangan ini membawa banyak dampak positif bagi keberlangsungan arus informasi sebagai satu ciri masyarakat yang inklusif dan demokratis. Dalam hal ini, arus informasi publik tidak lagi menjadi milik media-media mainstream yang akhir-akhir ini selalu dicurigai sebagai alat kepentingan.
\end{abstract}

\section{Keywords :}

Media online, hoax, jurnalis

\section{A. Pendahuluan}

Beralihnya dari media konvensial ke media online menjadi babak baru dalam dunia broadcast, menjadi tantangan tersendiri terhadap dinamika dunia jurnalis. Tingginya konsentrasi dan kebutuhan masyarakat akan informasi, semakin meningkatnya intensitas masyarakat dalam berdunia maya. Sebagian besar aktivitasnya dihabis untuk bermedia online. Memandang hal tersebut, informasi sudah menjadi faktor determinan kehidupan dunia maya sehingga menstimulus hadirnya, atau munculnya media-media baru, khusunya media online.

Namun, yang disayangkan munculnya media baru, tidak semua mampu memberikan informasi yang akurat, terpercaya dan bertanggung jawab, justru sebagian dari media online tersebut, melakukan praktek pemberitaan hoax atau secara luas dikenal dengan fake news, sehingga yang timbul pengkasifikasian dari media online itu sendiri, antara media online 
yang terpercaya dengan media "abal-abal". Media baru ini bahkan berubah menjadi alat kepentingan paling efektif untuk membentuk opini publik saat ini. Dengan memanfaatkan rendahnya daya nalar sebagian besar pengguna aplikasi, media baru sering digunakan sebagai alat pembunuhan karakter lawan-lawan politik dengan sumber data "hoaks".

Maraknya industri media online dewasa ini memberikan peluang bagi siapapun karena dari sisi pembuatan media online tergolong mudah, tidak seperti yang dilakukan oleh media konvensional yang membutuhkan infrastruktur, sumberdaya manusia dan manajemen yang lebih kompleks. Media online hanya bermodal alamat situs (website) sudah dapat beroperasi, disamping itu dari sisi anggaran, manajemen dan sumberdaya manusia tergolong murah.

Pada umumnya, hadirnya media online di tengah masyarakat tidak lebih dilatarbelakangi praktek bisnis yang sangat berorientasi pada kepentingan pasar (market) dibanding sebagai penyedia informasi yang mengedukasi. Idealisme media online tidak lagi dilihat sebagai mekanisme bisnis media yang tetap mempersyaratkan nilai dan etika jurnalis dalam kerja pemberitaanya. Hal demikian, menjadi suatu koreksi dan kritik dalam dunia jurnalis online dewasa ini. Sehingga mudahnya berita hoax yang terjadi pada media online karena tidak jelas statusnya, tidak mentaati prinsip-prinsip dasar penyiaran, tidak memerhati aspek nilai dan etika jurnalis pada pemberitaan.

Jika ditinjau dari segi hukum keberadaan Undang-undang Pers No. 40 tahun 1999 dan Undang-undang Penyiaran No. 32 tahun 2002 tentang Penyiaran, membawa banyak perubahan bagi dinamisasi kehidupan media di Indonesia, terutama berkaitan dengan kebebasan memperoleh dan menyebarluaskan informasi. Salah satu indikator adanya kebebasan tersebut ditandai dengan peningkatan jumlah penerbitan media cetak. Berdasarkan data yang dihimpun Direktorat Pembinaan Pers tahun 1999, jumlah penerbitan media massa cetak di Indonesia yang meliputi surat kabar, tabloid, majalah dan bulletin mencapai 1.687. Apabila dibandingkan dengan tahun 1997 jumlah penerbitan yang ada hanya $289^{1}$ Demikian halnya media-media konvensional yang beralih pada media online, memberikan suatu gambaran dengan massifnya media-media baru yang belum tentu berekses positif.

Kota Makassar sebagai salah satu kota terbesar yang ada Indonesia, dengan jumlah penduduk 1,5 juta penduduk yang rata-rata melek media informasi, berpeluang menjadi pasar

\footnotetext{
${ }^{1}$ https://bincangmedia.wordpress.com/2009/11/24/hijrah-bermedia-massa-dengan-jurnalisme-dakwah/ di akses pada
} tanggal 1 maret 2018 
(market) bagi industri media online. Oleh karena itu keberadaan media online di kota tersebut tergolong tinggi. Namun kasusnya, seperti yang dijelaskan sebelumnnya, maka penelitian ini akan menelaah dan menfokuskan pemberitaan hoax sekaitan dengan keberadaaan media online.

Sejauh ini, media yang dimaksud merupakan media yang mengimformasikan berita secara langsung tanpa mengolah (writing/news editing) dan menyajikan (presenting) dengan baik, dengan prinsip nilai dan etika jurnalisme. Menyikapi pemberitaan hoax yang tidak diawali dari kelembagaan akan tetap memunculkan preseden yang buruk dalam dunia media online. Tujuan media hadir di masyarakat tidak lain sebagai bentuk edukasi informasi.

Pemberitaan hoax seakan sudah menjadi hal yang lumrah, pemerintah menyoroti hoax pun kewalahan, pada tahun 2016 pemerintah telah memblokir 700 ribu situs, namun setiap harinya pula berita hoax terus bermunculan, tidak mampu menfilter dan membendung pemberitaan tersebut, walaupun sudah ada produk hukum seperti Undang-Undang Republik Indonesia Nomor 11 tahun 2008 tentang Informasi dan Transaksi Elektronik Pasal 28 Ayat 1 belum menimbulkan efek jerah terhadap pelaku hoax. Kerja polisi cyber dalam menanangani hoax masih tergolong rendah, belum didukung perangkat yang ada, serta sumber daya baik secara kualitas maupun kuantitas. Ditambah prilaku masyarakat dalam dunia maya yang langsung menyerap berita, menyebarluarkan tanpa mempertimbangkan kebenaran dan keaslian suatu berita menjadi suatu gambaran keluguan masyarakat yang tidak didukung dengan referensi literasi media. Sehingga kontribusi media online diharapkan memiliki peran aktif dalam menepis berita hoax.

Kerjasama seluruh pihak dalam menepis berita hoax menjadi kewajiban seluruh elemen masyarakat utama pada media online itu sendiri. Media online diharapkan memberikan edukasi, merumuskan secara konseptual terkait citizen journalist yang beretika. Utamanya memahami berita yang diadakan sesuai dengan realitas sesungguhnya, kasus atau peristiwa yang sebenarnya digali, telusuri dan memverifikasi informasi dan dikemas sebaik mungkin agar khalayak tertarik untuk membacanya. Menghindari dan mengambil berita dari media sosial lalu dikemas ulang dan disebarkan kembali ke media sosial. Berita yang memiliki referensi terkait jurnalisme. Kewajiban membaca dengan teliti dan menelusuri sumber dari berita tersebut dan yang terpenting adalah jangan terlalu mudah untuk menyebarluaskan berita tersebut sebelum berita tersebut diketahui keasliannya. 
Media di satu sisi diharapkan untuk menepis informasi yang bermuatan hoax, baik melalui penelusuran informasi, edukasi informasi kepada masyarakat, yang utama adalah menekan praktek hoax dari media online sendiri supaya media online sendiri memiliki tingkat kepercayaan dalam memberikan informasi. Berdasarkan latar belakang tersebut, menunjukkan adanya permasalahan media online dan terkait pemberitaan hoax yang perlu dilakukan kajian penelitian. Salah satu fokus dari penelitian ini adalah akan mendeskripsikan bagaimana media online di Kota Makassar dalam mengedukasi informasi kepada masyarakat dengan mempertimbangkan prinsip, nilai dan etika jurnalisme agar terhindar dari praktek pemberitaan hoax.

\section{B. Media Online}

Media online sebagai medium komunikasi massa, mengalami perkembangan komunikasi akhir-akhir ini, terutama secara teknologi tidak pernah ada satu garis perkembangan yang tunggal. Kendati label-label imbuhan seperti "Era Digital” mungkin ada gunanya dan membuka pikiran kita terhadap fenomena masa lampau dan masa kini. Ciri utamanya adalah "kompleksitas".

Beragamnya perspektif tentang komunikasi massa telah dilontarkan oleh para ahli dan pakar komunikasi. Namun demikian, dari sekian banyak dan ragam titik tekan yang dikemukakan, terdapat benang merah satu sama lain. Definisi komunikasi massa yang paling sederhana dikemukakan oleh Bittner. Bittner mendefinisikan komunikasi massa adalah pesan yang dikomunikasikan melalui media massa pada sejumlah besar orang (mass comunication is message comunicated through mass medium to a large number of people $)^{2}$.

Di era digitalisasi dan globalisasi seperti sekarang ini, berita informasi tidak hanya bisa kita dapatkan lewat media cetak seperti surat kabar, majalah dan sebagainya maupun media elektronik seperti televisi dan radio. Media online yang dipandang sebagai media interaktif juga dapat berfungsi sebagai media yang menyediakan berbagai informasi di dalamnya, termasuk berita. Keberadaan internet di tengah masyarakat saat ini dimanfaatkan sebagai saluran untuk menyampaikan informasi dengan jangkauan dan kapasitas yang jauh lebih masif. Pengetahuan yang memadai dan kemudahan mengaksesnya membuat

\footnotetext{
2 Jalaludin Rakhmat. (2007). Psikologi Komunikasi. Bandung: PT. Remaja Rosdakarya, hlm. 188.
} 
masyarakat semakin akrab dengan internet, sehingga sebagian khalayak masyarakat kini mulai mengonsumsi informasi sehari-hari melalui internet. Hasil survei tahun 2015- 2016 mengenai tingkat penggunaan internet di Indonesia yang dilakukan Pusat Kajian Komunikasi (PUSKAKOM) UI dan Asosiasi Penyelenggara Jasa Internet Indonesia (APJII) menunjukkan bahwa jumlah pengguna internet di Indonesia mencapai angka 88,1 juta orang. Survei tersebut juga menyatakan, bahwa penggunaan internet untuk mengonsumsi informasi cukup tinggi, menduduki urutan kedua setelah social networking (jejaring sosial).

\section{Tinjauan Pemberitaan Palsu (Hoax)}

Hoax atau berita palsu adalah usaha untuk menipu atau mengakali pembaca/pendengarnya untuk mempercayai sesuatu, padahal sang pencipta berita palsu tersebut tahu bahwa berita tersebut adalah palsu. Salah satu contoh pemberitaan palsu yang paling umum adalah mengklaim sesuatu barang atau kejadian dengan suatu sebutan yang berbeda dengan barang/kejadian sejatinya. Suatu pemberitaan palsu berbeda dengan misalnya pertunjukan sulap; dalam pemberitaan palsu, pendengar/penonton tidak sadar sedang dibohongi, sedangkan pada suatu pertunjukan sulap, penonton justru mengharapkan supaya ditipu (Wikipedia, n.d.).

Menurut pandangan psikologis, ada dua faktor yang dapat menyebabkan seseorang cenderung mudah percaya pada hoax. Orang lebih cenderung percaya hoax jika informasinya sesuai dengan opini atau sikap yang dimiliki (Respati, 2017). Secara alami perasaan positif akan timbul dalam diri seseorang jika opini atau keyakinannya mendapat afirmasi sehingga cenderung tidak akan mempedulikan apakah informasi yang diterimanya benar dan bahkan mudah saja bagi mereka untuk menyebarkan kembali informasi tersebut. Hal ini dapat diperparah jika si penyebar hoax memiliki pengetahuan yang kurang dalam memanfaatkan internet guna mencari informasi lebih dalam atau sekadar untuk cek dan ricek fakta.

Terdapat empat mode dalam kegiatan penemuan informasi melalui internet, diantaranya adalah:

1. Undirected viewing, seseorang mencari informasi tanpa tahu informasi tertentu dalam pikirannya. Tujuan keseluruhan adalah untuk mencari informasi secara luas dan sebanyak mungkin dari beragam sumber informasi yang digunakan, dan informasi yang didapatkan kemudian disaring sesuai dengan keinginannya. 
2. Conditioned viewing, seseorang sudah mengetahui akan apa yang dicari, sudah mengetahui topik informasi yang jelas, Pencarian informasinya sudah mulai terarah.

3. Informal search, seseorang telah mempunyai pengetahuan tentang topik yang akan dicari. Sehingga pencarian informasi melalui internet hanya untuk menambah pengetahuan dan pemahaman tentang topik tersebut. Dalam tipe ini pencari informasi sudah mengetahui batasan-batasan sejauh mana seseorang tersebut akan melakukan penelusuran. Namun dalam penelusuran ini, seseorang membatasi pada usaha dan waktu yang ia gunakan karena pada dasarnya, penelusuran yang dilakukan hanya bertujuan untuk menentukan adanya tindakan atau respon terhadap kebutuhannya.

4. Formal search, seseorang mempersiapkan waktu dan usaha untuk menelusur informasi atau topik tertentu secara khusus sesuai dengan kebutuhannya. Penelusuran ini bersifat formal karena dilakukan dengan menggunakan metode-metode tertentu. Tujuan penelusuran adalah untuk memperoleh informasi secara detail guna memperoleh solusi atau keputusan dari sebuah permasalahan yang dihadapi (Choo, Detlor, \& Turnbull, 1999).

Perilaku penyebaran hoax melalui internet sangat dipengaruhi oleh pembuat berita baik itu individu maupun berkelompok, dari yang berpendidikan rendah sampai yang tinggi, dan terstruktur rapi. (Lazonder, Biemans, \& Wopereis, 2000) menunjukkan bahwa terdapat perbedaan antara seseorang yang memiliki keahlian khusus dalam menggunakan search engine dengan orang yang masih baru atau awam dalam menggunakan search engine. Mereka dibedakan oleh pengalaman yang dimiliki. Individu yang memiliki pengalaman lebih banyak dalam memanfaatkan search engine, akan cenderung lebih sistematis dalam melakukan penelusuran dibandingkan dengan yang masih minim pengalaman (novice) ${ }^{3}$.

\section{Nilai dan Etika Jurnalis}

Moral dan etika pada hakekatnya merupakan prinsip dan nilai-nilai yang menurut keyakinan seseorang atau masyarakat dapat diterima dan dilaksanakan secara benar dan layak. Dengan demikian, prinsip dan nilai-nilai tersebut berkaitan dengan sikap yang benar dan yang salah yang mereka yakini. Etika sendiri sebagai bagian dari falsafah merupakan

\footnotetext{
${ }^{3}$ https://mti.binus.ac.id/2017/07/03/penyalahgunaan-informasiberita-hoax-di-media-sosial/ diakses pada tanggal 1 Maret 2018
} 
sistem dari prinsip-prinsiop moral termasuk aturan-aturan untuk melaksanakannya.

Dalam kajian hukum dan media massa, moral dan etika tersebut dikaitkan pada kewajiban para jurnalistik antara lain seperti; pelaksanaan kode etik jurnalistik dalam setiap aktivitas jurnalistiknya, tunduk pada institusi dan peraturan hukum untuk melaksanakan dengan etiket baiknya sebagaimana ketentuan-ketentuan di dalam hukum tersebut yang merupakan perangkat prinsip-prinsip dan aturan-aturan yang pada umumnya sudah diterima dan disetujui oleh masyarakat. Sehubungan dengan hal itu, prinsip etika bagi profesi jurnalistik memberikan dasar hukum bagi pengelolaan pemberitaan di media secara tertib dalam hubungan antar subyek hukum.

Etika berfungsi umumnya untuk melindungi kepentingan manusia, sehingga pelaksanaan jurnalistik wartawan dapat berlangsung dan dirasakan oleh manusia bahwa pemberitaan tersebut berfungsi dan berkenan bagi rasa tenteram dan damai. Dalam hal ini, maka peranan dari penegakan etika profesi jurnalisme tersebut sangat dominan. Kemudian untuk mencapai tegaknya etika dan berfungsinya hukum, maka hukum dan penegakan etika itu harus berada atau dalam keberadaan yaitu berfungsi sebagai kontrol sehingga tercapai tata tentram kerta raharja ${ }^{4}$. Tujuan pokok dari rumusan etika dalam Kode Etik profesi antara lain:

1. Standar etika, menjelaskan dan menetapkan tanggung jawab kepada lembaga dan masyarakat umum.

2. Membantu para profesional dalam menentukan apa yang harus mereka perbuat dalam menghadapi dilema pekerjaan mereka.

3. Standar etika bertujuan untuk menjaga reputasi atau nama para tenaga professional.

4. Untuk menjaga kelakuan dan integritas para tenaga profesi.

5. Standar etika juga pencerminan dan pengharapan dari komunitasnya, yang menjamin pelaksanaan Kode Etik tersebut dalam pelayanan ${ }^{5}$.

\section{E. Pembahasan}

\section{Media online ikut berkontribusi dalam menepis pemberitaan hoax}

Berdasarkan hasil penelusuran berbagai lembaga, baik lembaga-lembaga di bawah

\footnotetext{
${ }^{4}$ https://media.neliti.com/media/publications/12279-ID-hukum-profesi-jurnalistik-dan-etika-media-massa.pdf diakses pada tanggal 1 maret 2018

${ }^{5}$ Kusmandi, dan Samsuri.(2010). Undang-Undang Pers dan Peraturan-Peraturan Dewan Pers. Jakarta: Dewan Pers.
} 
struktur negara seperti kementerian informasi dan dewan pers, maupun lembaga-lembaga independen, berita hoax atau fake news sebenarnya lebih banyak beredar di media sosial. Fenomena ini sebagai dampak dari perkembangan teknologi dan sekaligus fitur komunikasinya yang semakin canggih seperti kehadiran facebook, twitter, instragram, dan lain sebagainya. Akun pada media-media tersebut adalah kepribadian yang mewakili tiap individu di dunia nyata. Menurut data Asosiasi Penyelenggara Jasa Internet Indonesia (APJII), pengguna internet di Indonesia sudah mencapai 143,26 di tahun 2017, dan mereka memastikan pada tahun 2018 jumlahnya meningkat dua kali lipatnya. ${ }^{6}$

Sementara kecanggihan teknologi mendukung setiap individu di tengah masyarakat untuk menjadi bagi dari transformasi kabar secara langsung di media sosial. Mirisnya, sebagian besar pengguna media sosial juga memiliki tingkat literasi yang rendah, khususnya pada aspek kemampuan melakukan verifikasi atas sebuah informasi. Bahkan sebagian media sosial dengan akun palsu dibuat dengan sengaja untuk kepentingan politik. Akun-akun tersebut kemudian digunakan sebagai alat propaganda dan pemuatan agenda-agenda kampanye hitam untuk membunuh karakter lawan politik. Dengan melihat angka pengguna internet di Indonesia, media sosial memang merupakan alat penyebarluasan informasi yang paling efektif saat ini.

Saat ini penyebarluasan informasi hoaks masih terjadi secara massif melalui mediamedia sosial. Sulitnya mengendalikan penyebaraluasan hoaks di media sosial karena akun di media-media tersebut bersifat pribadi. Sejauh ini, salah satu cara terbaik untuk melawan informasi hoaks adalah penguatan eksistensi media siber atau media online berbasis internet. Jumlah media online di Indonesia cukup besar, yaitu berdasarkan data Dewan Pers, jumlah media online pada tahun 2017 mencapai 43 ribu lebih media yang tersebar di seluruh tanah air. Jumlah ini dihitung Dewan Pers sejak tahun 2013, dan terdaftar di Dewan Pers hanya berjumlah 500 media online hingga pada tahun 2017. Bila dilihat dari segi jumlah, maka optimisme akan kehadiran media online dalam melawan hoaks cukup kuat. Hanya saja, sedikit mengejutkan karena sebagian besar diantara media online ini belum memiliki izin atau tidak terdaftar pada instansi berwenang dan belum melalui proses sertifikasi kelayakan sebagai sebuah media khususnya media online pada dewan pers.

Data di Sulawesi Selatan, menurut dewan pers dari ratusan total jumlah media online

${ }^{6}$ Dalam buletin APJIII edisi 22 Maret 2018 
yang terverifikasi hanya terdapat 4 media siber. Data ini dikuatkan keterangan dari Ketua Serikat Media Siber Indonesia Sulawesi Selatan (SMSI), Rasyid Al Farisi. Menurutnya, untuk sampai pada verifikasi dewan pers, ratusan media online di Sulsel akan mengalami banyak kendala, terutama halangan dari segi sumber daya manusia, dan administrasi perusahaan media.

Sumber daya manusia menurut Rasyid sangat berpengaruh pada produk berita yang diterbitkan ke publik karena jurnalis merupakan ujung tombak dari proses jurnalistik di setiap media massa. Berkualitas atau tidaknya sebuah karya jurnalistik sangat dipengaruhi oleh sumber daya jurnalis, baik dari segi wawasan, keterampilan menulis, maupun dari segi moralitasnya. Rasyid mengungkapkan, cerdas dan pandai menulis berita saja, tidak cukup untuk menjadi seorang jurnalis. Seorang jurnalis, kata Rasyid, mesti memiliki tanggungjawab moril terhadap setiap kegiatan jurnalistiknya agar tidak melahirkan berita yang memiliki dampak buruk bagi kehidupan publik.

Seperti pada profesi lainnya, pelanggaran dan penyalagunaan profesi jurnalisme masih lumrah terjadi di tengah-tengah kehidupan berbangsa dan bernegara. Ironinya, profesi jurnalisme telah memiliki berbagai perangkat aturan kode etik yang justru sering dilanggar untuk kepentingan sesaat. Menurut Rasyid, hal ini terjadi karena tanggungjawab moril tadi, tidak melekat dan menjadi bagian dari diri atau ideologi jurnalis. Lebih lanjut, Rasyid menerangkan bahwa fenomenanya sangat mudah ditemukan sekarang ini di media-media berbasis internet. Tidak hanya situs berita dadakan, tetapi dapat pula ditemukan pada mediamedia yang dikelola secara profesional oleh jurnalis. Di antaranya masih mengedepankan isi yang bombastis, sementara dari segi penegakan prinsip-prinsip jurnalisme dalam berkarya sangat minim dipratikkan oleh jurnalis dari media bersangkutan.

Fenomena berita bombastis yang sering ditemukan seperti penulisan berita yang bermain pada topik-topik kekerasan. Biasanya, media siber tertentu senang menekankan penulisan tindak kekerasan pada bagian judulnya sehingga dapat meningkatkan animo pembaca terhadap berita terkait. Dengan demikian, ratingnya meningkat di jagat maya. Ironinya, banyak kasus berita judul memanfaatkan pula atau mengeksploitasi topik-topik kekerasan terhadap perempuan di media online.

Ringkasnya, banyaknya fenomena seperti di atas karena faktor tanggungjawab moril jurnalis tertentu yang minim terhadap publik. Minimnya ditunjukkan dari abainya jurnalis 
pada pertanyaan-perntayaan kritis seperti, seberapa penting sebuah berita itu dimuat? Apa manfaatnya? Dan, apa dampaknya bagi kehidupan publik, baik dari segi sosial, ekonomi, politik, budaya, dan lain sebagainya. Apa akibatnya bagi objek pemberitaan, terutama bagi kalangan perempuan yang sering menjadi korban tindak kekerasan.

Pengaruh rendahnya kualitas dan keterampilan jurnalis termasuk berpengaruh pada tahapan-tahapan pra produksi berita seperti kegiatan liputan atau pengumpulan data di lapangan. Rasyid mengungkapkan sebagai berikut :

"Jadi sangat jauh ketika kita bicara verifikasi. Untuk dikategorikan saja sebagai media yang karyanya bisa memenuhi kaidah jurnalisme saja tidak. Ratusan media online hanya beberapa saja yang memenuhi persyaratan sehingga dapat disebut sebagai media profesional atau media siber. Dari sisi berita misalnya, sebagian besar juga masih menggunakan model copy paste. Tidak patuh pada rumus dan kaidah jurnalisme. Misalnya pada prinsip-prinsip keberimbangan, cek and ricek ke lapangan, independensi, dan lain sebagainya. Saat kami meminta media-media yang tergabung dalam IMSI di sejumlah daerah, banyak yang angkat tangah setelah melihat persyaratan kami ajukan. IMSI memberlakukan syarat yang ketat agar bisa memenuhi persyaratan verifikasi Dewan Pers. Kita sebut saja satu daerah misalnya, dari data yang kami peroleh, di Kabupaten Soppeng saja, jumlah media online mencapai puluhan, tapi satu dua saja yang sanggup."

Pada tingkat tertentu, kurangnya tanggungjawab moril dan rendahnya kualitas jurnalis bisa menyebabkan lahirnya informasi hoaks. Hal ini bisa terjadi bila pencarian data tidak disertai dengan disiplin verifikasi ke lapangan dan ke sumber-sumber berita. Di tengah banjir informasi saat ini, verifikasi media online sangat dibutuhkan untuk menciptakan stabilitas publik. Dengan verifikasi, maka setiap media online dapat bertanggung jawab secara sosial, budaya, ekonomi dan politik terhadap pembacanya. Tanggung jawab media dalam konteks sosial, budaya, dan politik adalah sebagai wahana peynampai pesan-pesan positif dan konstruktif baik secara sosial, budaya, ekonomi dan politik. Positif dalam ideologi media massa yaitu selama isi pemberitaan memuat informasi yang berpihak kepada kepentingan publik, atau warga negara yang termarginalkan oleh sistem kekuasaan, baik negara maupun kekuasaan informal yang banyak dipratikkan oleh organisasi sipil.

Verifikasi menuntut setiap pengelola media online untuk memenuhi sejumlah syarat yang diajukan dari Dewan Pers, di antaranya sumber daya jurnalis yang memahami fungsi dan tugas jurnalisme, kaidah-kaidah penulisan jurnalistik dan patuh pada kode etik serta keterampilan dalam penulisan jurnalistik. Tiga elemen ini memiliki peran penting dalam membentuk pola pikir 
dan cara pandang seorang jurnalis terhadap sebuah peristiwa atau momentum yang terjadi di dalam kehidupan sehari-hari.

Karya jurnalisme merupakan hasil pengalaman pribadi jurnalis atas sebuah fenomena, lalu dikonstruksi melalui proses berpikir sehingga subjektifitas dan interest seorang jurnalis sangat berpeluang ikut dalam bangunan tulisan berita yang dibuat. Sebab itu, hasil olah pikir tersebut mesti dibingkai dalam satu tujuan, yaitu untuk kepentingan publik.

Di era berkembangnya media berbasis internet saat ini, pemanfaatan jurnalisme untuk menyebarluaskan berita yang sarat dengan kepentingan pribadi dan kelompok meningkat pesat. Bahkan informasi-informasi bohong dapat dimodifikasi sebagai karya jurnalistik melalui situssitus online yang dengan mudah dibuat sekarang ini. Dengan bermodal domain murah, bahkan gratis, setiap individu sudah bisa membuat situs berita sendiri. Tampilan juga bisa tampak sangat bagus. Begitu pula kolom-kolom beritanya, tampak sangat profesional, tetapi bila ditilik lebih dalam dari segi isi, maka sangat mudah mengidentifikasi dan mengenalinya sebagai media online abal-abal.

\section{Media online menerapkan prinsip nilai dan etika jurnalis dalam pemberitaannya}

Dalam Peraturan Dewan Pers Nomor 1/Peraturan-DP/III/2012 tentang Pedoman Pemberitaan Media Siber diungkapkan bahwa media siber dalam melakukan kegiatan jurnalistik terikat pada ketentuan dalam Undang-Undang No. 40 Tahun 1999 tentang Pers. Prinsip-prinsip etika jurnalistik yang diterapkan pada institusi pers konvensional juga berlaku bagi media siber. Beberapa di antaranya yaitu menyangkut verifikasi dan keberimbangan berita. Tidak memuat berita bohong, fitnah, sadis, dan cabul.

Disebutkan pula dalam Pedoman Pemberitaan Media Siber tersebut, bahwa pada prinsipnya setiap berita harus melalui verifikasi. Berita yang dapat merugikan pihak lain memerlukan verifikasi pada berita yang sama untuk memenuhi prinsip akurasi dan keberimbangan. Disebutkan pula, bahwa media siber juga harus menyediakan mekanisme untuk melakukan ralat, koreksi, dan pemuatan hak jawab. Singkatnya, peraturan tersebut mengatur secara ketat produk informasi media siber.

Dalam rangka menegakkan prinsip-prinsip kerja pers, Dewan Pers di Jakarta mencanangkan program sertifikasi media online. Sertifikasi ini melalui proses ketat yang menerapkan sejumlah persyaratan yang menjunjung tinggi tugas dan fungsi pers sebagai elemen ke empat kehidupan berdemokrasi. Menurut Muhammad Yunus, memenuhi persyaratan 
sertifikasi Dewan Pers, manajemen Makassar terkini telah menyiapkan infrastruktur kelembagaan, administrasi, dan sumber daya manusia sejak tahun 2015. Tidak heran bila tahun 2018, Makassar terkini bersama beberapa media online dari Kota Makassar, akhirnya dinyatakan lolos verifikasi faktual di Dewan Pers. Sementara ribuan media online lainnya tidak dapat memenuhi persyaratan sejauh ini. Sertifikasi ini bagi Yunus sangat penting dalam menciptakan informasi yang sehat di masa depan. Hal ini juga dapat menjamin profil media mereka sebagai media yang memiliki kredibilitas dan integritas terhadap kepentingan publik. Sebagaimana petikan wawancara Yunus berikut :

"Di masa mendatang, beberapa instansi pemerintah hanya akan bekerjasama dengan media yang terverifikasi faktual administrasi oleh dewan pers. Meski tidak mudah, kami berusaha memenuhi standar Dewan Pers. Makassar Terkini sebenarnya awalnya majalah yang kemudian berimigrasi ke online karena tuntutan perkembangan teknologi media. Tetapi kami sudah melakukan pendaftaran sejak 15 tahun lalu dan akhirnya terverifikasi di tahun 2018. Setelah terverifikasi kita langsung menjadi mitra Dewan Pers. Hal ini tentu memiliki pengaruh pada kredibilitas media kami sebagai penyedia informasi kepada publik."

Lebih lanjut, Yunus mengungkapkan dalam wawancara bahwa untuk memenuhi sertifikasi melalui verifikasi faktual administrasi ini, pihaknya harus memenuhi persyaratan sebagai berikut :

1. Pengelola atau redaksi minimal satu pimpinannya sudah punya sertifikat kompetensi jurnalis tingkat utama. Tingkat pemimpin atau manajemen. Aturan ini baru, sehingga banyak media-media online yang belum mampu memenuhi persyaratan ini.

2. Sistem penggajian. Dewan Pers mensyaratkan bahwa karyawan itu punya gaji standar minimal UMP atau UMK, dan terdaftar karywannya di BPJS baik kesehatan maupun ketenagakerjaan. Dan itu banyak yang gugur di situ.

3. Persoalan kantor. Banyak media online yang belum punya kantor tetap. Jadi ketika akan dihubungi, ketika ada sengketa berita, dll, sulit dihubungi. Di mana kantornya, siapa pimpinannya. Dewan Pers sangat ketat dalam hal ini karena ada verifikasi faktual langsung anggota dewan pers yang berkunjung ke kantor media bersangkutan. Melihat bagaimana proses-proses keredaksian berjalan, bagaimana 
memisahkan antara bisnis dan dapur redaksi

4. Aturan perusahaan tidak boleh lagi berjalan seperti PT Barang dan Jasa. Khusus perusahaan terbuka Pers saja. Tidak ada lagi perusahaan Pers sekaligus juga jasa jual beli barang atau perdagangan.

Usaha untuk diakui sebagai mitra Dewan Pers melalui verifikasi administrasi faktual, menunjukkan keseriusan media siber atau online di Kota Makassar untuk meningkatkan profesionalitas mereka dalam bidang jurnalistik. Usaha ini juga dapat dilihat sebagai bentuk kerja serius dari media online untuk dikenal sebagai media yang memiliki reputasi sebagai penyedia informasi berintegritas. Di Kota Makassar, media siber Makassar Terkini termasuk salah satu dari tiga media yang telah diverifikasi administrasi faktual di Dewan Pers. Dengan demikian, media ini dapat dinyatakan sebagai media berbasis pada kaidah jurnalisme.

Sejauh ini media online di Kota Makassar sulit untuk bisa memenuhi verifikasi faktual Dewan Pers. Hal ini disebabkan tidak siapnya media ini dari segi sumber daya manusia, badan usaha dan infrastruktur pendukung seperti kantor tetap, dan lain sebagainya. Data di Dewan Pers menunjukkan, media online yang terverifikasi administrasi faktual di Makassar hanya terdiri dari tiga media online, masing-masing Tribun Timur Online, Kabar Makassar, dan Makassar Terkini. Sementara media lainnya baru dalam tahap mempersiapkan diri untuk memenuhi standar-standar dalam verifikasi yang disiyaratkan oleh Dewan Pers.

\section{F. Kesimpulan}

1. Konstribusi media online dalam menepis pemberitaan hoaks yaitu terletak pada tugas dan fungsinya sebagi penyedia informasi yang terverifikasi. Dengan demikian pembaca memiliki alternatif bacaan untuk dijadikan alat konfirmasi terhadap berita hoaks yang beredar di media sosial.

2. Prinsip dan etika jurnalis adalah pentunjuk atau pedoman bagi jurnalis dalam menulis berita. Dalam menginjeksi pesan prinsip moral tersebut pada diri pribadi jurnalis, media online memberikan pelatihan rutin secara formal dan pelatihan informal yang berlangsung setiap saat dalam proses kerja keredaksian. Sebagian besar media siber juga mengikutkan jurnalisnya ikut dalam sertifikasi jurnalis, serta mengikuti verifikasi faktual administrasi yang dilakukan Dewan Pers.

3. Media Online mengedukasi masyarakat atau publik melalui penyediaan isi berita yang 
faktual dan terverifikasi dengan baik. Sebagian media online juga telah menyiapkan kolom cek fakta untuk memberikan informasi hasil penelusuran media terkait terhadap berita hoaks yang beredar di media sosial dan jejaring komunikasi sosial.

\section{A. Saran}

Berdasarkan kesimpulan di atas penulis pada penelitian ini mengemukakan saran sebagai berikut :

1. Besarnya arus informasi sebagai dampak dari perkembangan teknologi komunikasi digital merupakan keniscayaan yang mesti diterima oleh seluruh masyarakat modern saat ini. Begitu pula besarnya informasi hoaks sebagai dampak dari perkembangan tersebut. Namun media siber dalam hal ini masih menjadi sumber utama yang dapat dijadikan tolak ukur dalam menakar validitas sebuah informasi. Oleh karena itu, media siber diharapkan dapat mempertahankan posisinya tersebut dengan mengedepankan pemberitaan berbasis pada nilai-nilai bersama dan kepercayaan publik.

2. Hendaknya setiap perusahaan media mewajibkan sertifikasi jurnalis atau wartawan sebagai syarat dalam setiap penerimaan jurnalis di medianya. Melalui program tersebut kapasitas dan tingkat pemahaman jurnalis terhadap nilai dan kode etik jurnalis dapat diukur. Selain itu, pelatihan dan diskusi rutin secara formal perlu ditingkatkan secara internal di perusahaan media atau pers. Program ini juga perlu didukung oleh seluruh elemen terkait di luar perusahaan pers, seperti organisasi masyarakat sipil dan instansi pemerintah yang idealnya menjadikan sertifikasi wartawan sebagai pijakan dalam membuka kerjasama informasi dengan jurnalis dengan lembaga mereka.

3. Program cek fakta saat ini baru diterapkan secara terbatas oleh sejumlah media siber di Indonesia. Ke depan, akses terhadap tools cek fakta dan semacamnya mesti dibuka secara lebar dan meluas ke tengah publik dengan cara menggandeng lembagalembaga publik hingga organisasi kemasyarakatan, komunitas sosial, budaya, dan lain sebagainya yang menjadi representasi individu di tengah masyarakat. Hal ini sangat penting mengingat sumber informasi juga telah bergeser dari media massa ke individu akibat dari perkembangan teknologi komunikasi. 


\section{DAFTAR PUSTAKA}

Cangara, Hafied. 2006. Pengantar Ilmu Komunikasi. Jakarta : Raja Grafindo Persada Djuroto, Totok. 2004. Manajemen Penerbitan Pers. Bandung : Remaja Rosdakarya Effendy, Onong Uchjana. 2000. Ilmu Komunikasi Teori dan Praktek. Bandung : Remaja Rosdakarya.

Eriyanto. 2009. Analisis Wacana: Pengantar Analisis Teks Media. Yogyakarta : LKiS

Holmes, David. 2012. TEORI KOMUNIKASI : Media, Teknologi, dan Masyarakat. Yogyakarta : Pustaka Pelajar.

Kriyantono, Rachmat. 2010. Teknik Praktis Riset Komunikasi. Jakarta : Kakilangit Kencana Jakob Oetomo, 2006 Sejarah Sosial Media, Jakarta: Yayasan OBOR Indonesia.

Kusumaningrat, Hikmat dan Kusumaningkrat, Purnama. 2012. JURNALISTIK Teori dan Praktik. Bandung: Rosdakarya.

Littlejohn, Stephen W. 2009. Teori Komunikasi “Theories of Human Communication” edisi 9. Jakarta : Salemba Humanika

McQuail, Denis. 2011. Teori Komunikasi Massa McQuail, Edisi 6 Buku 1. Jakarta: Salemba Humanika

Meleong, Lexy J. 2007. Metode Penelitian Kualitaif. Bandung : Rosdakarya. Mulyana, Deddy Iskandar. 2008. Ilmu Komunikasi : Suatu Pengantar. Bandung : PT Remaja Rosdakarya Pawito. 2008. Penelitian Komunikasi Kualitatif. Yogyakarta : LKiS Pelangi Aksara Yogyakarta Rakhmat, Jalaluddin. 2009. Metode Penelitian Komunikasi. Bandung : Remaja Rosdakarya . 2007. Psikologi Komunikasi. Bandung: PT. Remaja Rosdakarya

Romli, Asep Syamsul M. 2012. Jurnalistik Online : Panduan Praktis Mengelola Media Online. Bandung : Nuansa Cendikia.

Santana, Septiawan. 2005. Jurnalisme Kontemporer. Jakarta : Yayasan Obor Indonesia Sobur, Alex. 2004. Analisis Teks Media. Bandung : Remaja Rosda Karya Suryawati, Indah. 2011. Jurnalitik : Suatu Pengantar Teori dan Praktek. Bogor : Ghalia Indonesia.

Syah, Sirikit. 2011. Rambu Rambu Jurnalistik. Yoyakarta : Pustaka Pelajar. Syaibani, Yunus Ahmad, dkk. 2011. New Media Teori dan Aplikasi. Karanganyar : Lindu Pustaka Kusmandi, dan Samsuri.2010. Undang-Undang Pers dan Peraturan-Peraturan Dewan Pers. Jakarta: Dewan Pers.

Yulia, Wanda. 2010. Andai Aku Jadi Penyiar. Yogyakarta : C.V Andi Offset 